\title{
PENGARUH MARKET SIZE, KINERJA PERUSAHAAN, NILAI PERUSAHAAN, LEVERAGE, DAN KESEMPATAN BERTUMBUH TERHADAP STOCK RETURN
}

\author{
REFAN LEONARDO WISUTA \\ STELLA \\ STIE Trisakti \\ refan.leonardo@gmail.com \\ stella@stietrisakti.ac.id
}

\begin{abstract}
The purpose of this research is to test and analyze empirically the influence of market size, firm performance, firm value, leverage, and growth opportunity toward stock return. The object of this research is coal mine sector companies that listed in Indonesia Stock Exchange period 2010-2014. The purposive sampling is used as sampling technique, where 8 companies met the criteria and were analyzed using Eviews8 panel data regressions with random effect model to test the hypothesis. The result of this research shows firm performance and firm value influence stock return. While market size, leverage and growrh opportunity do not influence stock return.
\end{abstract}

Keywords: stock return, market size, firm performance, firm value, leverage, growth

Abstrak: Tujuan penelitian adalah untuk menguji dan menganalisis pengaruh market size, kinerja perusahaan, nilai perusahaan, leverage dan kesempatan bertumbuh terhadap stock return.Objek penelitian adalah perusahaan sektor batubara yang terdaftar di Bursa Efek Indonesia periode 2010-2014. Purposive sampling digunakan sebagai teknik pemilihan sampel, 8 perusahaan yang memenuhi kriteria dan dianalisis menggunakan regresi data panel dengan alat uji Eviews 8 dan model random effect untuk menguji hipotesis.Hasil penelitian ini menunjukkan bahwa kinerja perusahaan dan nilai perusahaan berpengaruh terhadap stock return. Sedangkan market size, leveragedan kesempatan bertumbuh tidak berpengaruh terhadap stock return.

Kata Kunci: stock return, market size, kinerja perusahaan, nilai perusahaan, leverage, kesempatan bertumbuh 


\section{PENDAHULUAN}

Pasar modal (Capital Market) merupakan pasar untuk berbagai instrumen keuangan yang bisa diperjual belikan misalnya obligasi, saham, dan reksadana sebagai sarana investasi. Undang-undang Pasar Modal No. 8 Tahun 1995 tentang Pasar Modal mendefinisikan pasar modal sebagai "kegiatan yang bersangkutan dengan penawaran umum dan perdagangan efek, perusahaan publik yang berkaitan dengan efek yang diterbitkannya, serta lembaga dan profesi yang berkaitan dengan efek". Pasar modal memiliki 2 peran yaitu (1) sebagai sarana bagi pendanaan usaha atau mendapatkan dana dari masyarakat pemodal (investor) (2) pasar modal adalah sarana bagi masyarakat untuk berinvestasi pada instrumen keuangan. Pasar modal yang efisien merupakan pasar modal yang harga-harga sekuritasnya mencerminkan semua informasi yang relevan dalam sekuritas (Hayati, 2010)

Investor menginvestasikan dananya kepada instrument keuangan dengan harapan agar return yang dihasilkan dimasa yang akan datang sesuai dengan besarnya modal yang diinvestasikan. Namun return yang besar selalu diikuti oleh risiko yang besar seperti dua mata koin yang tidak dapat dipisahkan. Actual return hampir selalu berbeda dengan expected return (Acheampong et al. 2014).

Dari berbagai jenis instrumen keuangan yang dijual di pasar modal, saham adalah instrumen keuangan yang paling menarik perhatian investor daripada obligasi karena saham dicetak dalam jumlah sangat banyak dan harga yang jauh lebih murah perlembarnya dibandingkan dengan obligasi sehingga perusahaan bisa mendapatkan dana segar dari banyak investor.

Banyaknya saham yang dicetak oleh sebuah perusahaan dapat diindikasikan oleh investor sebagai sinyal-sinyal pengembangan perusahaan. Saham-saham yang dicetak diindikasikan sebagai kebutuhan modal dalam pengembangan usaha sehingga saham yang dicetak diharapkan dapat memberikan dana segar bagi perusahaan. Harga saham juga dapat diindikasikan sebagai tolok ukur kesejahteraan investor dan perusahaan. Harga saham terbentuk dari permintaan dan penawaran investor sehingga harga saham merupakan Fair Price yang dapat dijadikan proksi nilai perusahaan. (Fidhayatin dan Dewi 2012)

Modligliani-Miller (1958) (dalam Prince et al. 2014) mengatakan bahwa proporsi DER akan meningkatkan hutang dalam struktur modal dalam pergeseran pasar. Leverage merupakan aktivitas untuk membuat investasi melalui pinjaman (Prince et al. 2014). Financial leverage dan dampaknya terhadap investasi perusahaan merupakan salah satu topik sentral dalam keputusan keuangan perusahaan (Shengdan Shuyang 2014). Leverage dalam struktur modal adalah salah satu keputusan alternatif. Perusahaan dalam membuat strategi investasi dalam keputusan keuangan perusahaan untuk mendapat return.

Untuk meminimalisir risiko yang dihadapi investor dalam berinvestasi, investor dapat melakukan analisis fundamental dengan cara menganalisis nilai perusahaan (Pamadanu 2011). Nilai perusahaan adalah harga yang bersedia dibayar oleh calon pembeli apabila perusahaan tersebut dijual (Pamadanu 2011). Nilai pasar dalam hal ini menggunakan proksi Market to Book Value. Proksi Market to Book Value dipilih karena dianggap memberikan pengakuan masyarakat terhadap kinerja keuangan yang dapat dicapai perusahaan dan memberikan gambaran mengenai seberapa besar perusahaan berkaitan dengan harga saham sebuah perusahaan (Wibawa dan Sudjarni 2012).

Investor yang berinvestasi pada saham menginginkan return pada tingkat tertentu yang disebut dengan stock return. Peningkatan/penurunan stock return oleh investor ditentukan oleh kinerja keuangan perusahaan yang diproyeksikan 
dalam laporan keuangan perusahaan (Wibawa dan Sudjarni 2012). Salah satu instrumen kinerja keuangan merupakan profitabilitas yang diukur dengan Return on Equity yang menggambarkan rasio besar laba bersih setelah pajak yang dibandingkan dengan modal saham perusahaan (Wibawa dan Sudjarni 2012). Rasio ini dapat menarik calon investor dan manajemen karena mencerminkan kemampuan perusahaan dalam mengelola modalnya (Fidhayatin dan Dewi 2012)

Bertumbuhnya perusahaan akan menciptakan banyak sekali pilihan investasi sebagai strategi keuangan perusahaan untuk menciptakan return dimasa yang akan datang disebut dengan Investment Opportunity Set (IOS). Investasi yang dilakukan oleh perusahaan tidak hanya berasal dari modal dalam perusahaan tetapi melibatkan dana yang didapat dari investor (Anugrah 2009). Dalam penilitian yang dilakukan Myers (1997) nilai suatu perusahaan adalah kombinasi antara aset yang dimiliki dengan pilihan investasi pada masa depan. Proksi IOS menggunakan Rasio Capital Expenditure to Book Value of Asset (CAPBVA) yang digunakan oleh Anugrah (2009) untuk melihat besarnya aliran tambahan modal saham perusahaan.

Market Size (Market Capitalization) adalah ukuran perusahaan yang diukur dari harga saham pada periode tertentu dikalikan dengan jumlah saham beredar. Investor tertarik dengan perusahaan yang memiliki ukuran atau pasar kapitalisasi yang besar. Saham-saham perusahaan yang memiliki kapitalisasi besar menjadi incaran investor karena dianggap mempunyai potensi bertumbuh yang tinggi dan risiko yang rendah. Hasil penelitian yang telah dilakukan masih mencerminkan adanya perbedaan korelasi yang signifikan terhadap stock return sehingga memerlukan identifikasi kembali faktor-faktor spesifik yang mempengaruhi stock return secara signifikan.

Signaling theory menyatakan bahwa perusahaan yang berkualitas baik dengan sengaja akan memberikan sinyal pada pasar, dengan demikian pasar diharapkan dapat membedakan perusahaan yang berkualitas baik dan buruk (Hartono 2005). Kualitas keputusan investor dipengaruhi oleh kualitas informasi yang diungkapkan dalam laporan keuangan perusahaan. Kualitas informasi tersebut bertujuan untuk mengurangi asimetri informasi yang timbul ketika manajer lebih mengetahui informasi internal dan prospek perusahaan dimasa mendatang dibandingkan pihak eksternal perusahaan.

Informasi yang dipublikasikan perusahaan baik dalam bentuk laporan keuangan, promosi, atau pembuatan surat hutang berupa saham dan obligasi yang secara sadar atau tidak sadar telah memberikan sinyal bagi investor dalam membuat keputusan untuk menginvestasikan dananya kepada perusahaan. Sinyal yang diberikan perusahaan dapat berupa sinyal baik atau sinyal buruk. Keduanya berguna bagi investor untuk membeli surat hutang yang dicetak oleh perusahaan saat menangkap sinyal baik atau justru menjual surat hutang yang dimiliki saat menangkap sinyal yang tidak baik dari perusahaan.

Teori struktur modal modern yang pertama adalah teori Modigliani dan Miller (MM Theory). Mereka berpendapat bahwa struktur modal tidak relevan atau tidak mempengaruhi nilai perusahaan. Diungkapkan oleh Myers (2001), Perusahaan akan berhutang sampai pada tingkat hutang tertentu, dimana penghematan pajak (tax shields) dari tambahan hutang sama dengan biaya kesulitan keuangan (financial distress). Biaya kesulitan keuangan (Financial distress) adalah biaya kebangkrutan (bankruptcy costs) atau reorganization, dan biaya keagenan (agency costs) yang meningkat akibat dari turunnya kredibilitas suatu perusahaan. Trade-off theory dalam menentukan struktur modal yang optimal memasukkan beberapa faktor antara lain pajak, biaya keagenan (agency costs) dan biaya kesulitan keuangan (financial distress). Tingkat hutang yang optimal tercapai ketika penghematan pajak (tax shields) mencapai jumlah yang maksimal terhadap biaya kesulitan keuangan (costs of financial distress). 
Perusahaan-perusahaan dengan tingkat profitabilitas yang tinggi tentu akan berusaha mengurangi pajaknya dengan cara meningkatkan rasio hutangnya, sehingga tambahan hutang tersebut akan mengurangi pajak.

Menurut Eriemo (2014) market size adalah ukuran dari pasar yang dimiliki oleh perusahaan yang dapat diukur dari banyaknya jumlah saham yang dicetak. Proksi untuk mengukur market size menggunakan Market Capitalization. Kinerja perusahaan dapat dijadikan pedoman dalam mengukur keberhasilan suatu perusahaan. Kinerja perusahaan merupakan pengukuran atas prestasi perusahaan yang timbul akibat proses pengambilan keputusan manajemen, karena memiliki hubungan efektifitas pemanfaatan modal, efisiensi dan rentabilitas dari kegiatan kinerja (Fidhayatin dan Dewi 2012). Kinerja perusahaan merupakan pedoman dasar yang merefleksikan hasil dan prestasi dari aktivitas pengambilan keputusan yang dibuat perusahaan dalam mengalokasikan sumberdaya yang tersedia yang dapat dijadikan pedoman bagi investor dalam membuat keputusan investasi.

Nilai perusahaan merupakan bentuk memaksimalkan tujuan perusahaan melalui peningkatan kemakmuran para pemegang saham. Memaksimumkan kemakmuran pemegang saham adalah memaksimumkan present value keuntungan pemegang saham yang diharapkan dalam investasi (Fidhayatin dan Dewi 2012). Nilai perusahaan merupakan harga sebuah perusahaan dimata para investor yang dapat diukur melalui surat-surat hutang yang diterbitkan. Menurut Gitman dan Zutter $(2015,560)$ leverage merupakan penggunaan dari biaya-biaya tetap perusahaan yang bertujuan untuk memaksimalkan return dari saham.

Kesempatan bertumbuh perusahaan diukur menggunakan capbva. Rasio capital expenditure to book value asset digunakan untuk menunjukkan adanya aliran tambahan saham perusahaan pada aktiva produktif sehingga potensi perusahaan akan meningkat (Fidhayatin dan Dewi, 2012). CAPBVA adalah proksi yang digunakan untuk mengukur kesempatan bertumbuh sebuah perusahaan yang mengadakan tambahan saham sebagai tambahan investasi untuk memaksimalisasi potensi perusahaan. Stock return adalah hasil yang diharapkan dan diperoleh oleh investor sebagai imbal jasa terhadap sebagian investasi yang ditanamkan (Acheampong et al. 2014).

\section{METODE PENELITIAN}

Populasi di penelitian ini adalah perusahaan pertambangan yang tercatat (listed) di Bursa Efek Indonesia periode yang dimuat dalam IDX (Indonesia Stock Exchange). Karakteristik populasi dalam penelitian ini adalah perusahaan yang terdaftar di BEI pada subsektor batubara periode 2010-2014. Pemilihan sampel penelitian dilakukan dengan menggunakan metode purposive sampling, yaitu pengambilan sampel non-probabilistik berdasarkan pertimbangan atau pemilihan anggota sampel dengan mendasarkan pada kriteria tertentu.

Return merupakan hasil yang diperoleh dari investasi. Return dapat berupa return realisasi yang sudah terjadi dan return ekspetasi yang belum terjadi tetapi diharapkan akan terjadi dimasa yang akan datang (Fidhayatin dan Dewi 2012)

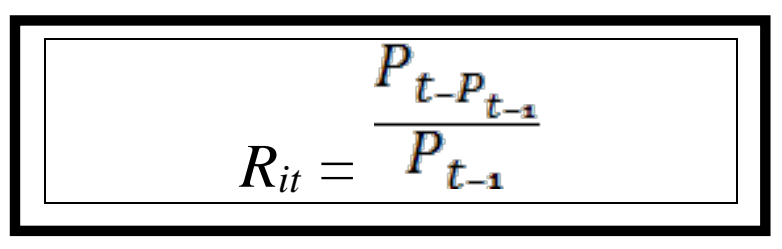

Kinerja perusahaan dapat dijadikan pedoman dalam mengukur keberhasilan suatu perusahaan. Kinerja perusahaan merupakan pengukuran atas prestasi perusahaan yang timbul akibat proses pengambilan keputusan manajemen, karena memiliki hubungan efektivitas pemanfaatan modal, efisiensi dan rentabilitas dari kegiatan kinerja (Fidhayatin dan Dewi 2012). 


$$
\text { ROE }=\frac{\text { Laba Bersih }}{\text { Modal Saham }}
$$

Nilai perusahaan adalah nilai jual suatu perusahaan dalam pasar modal. Nilai perusahaan dalam penelitian Fidhayatin dan Dewi (2014) dihitung menggunakan Market to Book Value.

\section{$M B V=$ Share Price Book Value Pershare}

$D E R$ is a proxy for estimating the level of leverage of a company. A company with high DER may provide higher returns to its shareholders, in line with the risk that is faced by the company compared to other companies with lower DER (Acheampong et al. 2014).

\section{Total Debt \\ $D E R=\overline{\text { Total Equity }}$}

IOS merupakan nilai perusahaan yang besarnya tergantung pada pengeluaran yang ditetapkan oleh manajemen pada masa yang akan datang dan merupakan investasi yang diharapkan untuk mendapatkan return yang lebih besar. Secara umum dapat dikatakan bahwa IOS menggambarkan tentang luasnya kesempatan atau peluang investasi bagi suatu perusahaan. Kesempatan bertumbuh diproksikan menggunakan Capital Expenditure to Book Value of Asset (CAPBVA) (Fidhayatin dan Dewi 2012).

$$
\begin{gathered}
\text { CAPBVA = } \\
\text { Nilai Bukut-Niai Buku} u_{t-1} \\
\text { Total Asset }
\end{gathered}
$$

\section{HASIL PENELITIAN}

Pengambilan sampel secara purposive sampling, maka jumlah perusahaan yang sesuai dengan kriteria adalah 8 perusahaan dan periode 2010-2014 dikarenakan dalam periode tersebut mencakup data paling banyak yang memenuhi persyaratan penelitian. Total jumlah data yang digunakan adalah sebanyak 40 data yang terdiri atas 8 perusahaan dengan jumlah periode selama 5 tahun.

Tabel 1 Hasil Statistik Deskriptif

\begin{tabular}{lcccccc}
\hline \hline \multicolumn{1}{c}{ Variabel } & SR & SIZE & ROE & MBV & LEV & CAPBVA \\
\hline \hline Mean & -2.409645 & 28.84559 & 0.139654 & 4.123650 & 1.028561 & 0.392947 \\
\hline Maximum & 218.5841 & 30.77922 & 0.685087 & 24.43426 & 3.546030 & 9.514946 \\
\hline Minimum & -96.02410 & 25.37196 & -0.739701 & 0.141104 & 0.176043 & -0.243307 \\
\hline Std. Dev. & 63.36225 & 1.764610 & 0.253011 & 4.999130 & 0.775522 & 1.509325 \\
\hline Observations & 40 & 40 & 40 & 40 & 40 & 40 \\
\hline
\end{tabular}


Tabel 2 Hasil Uji Hausman

\begin{tabular}{|c|c|c|c|}
\hline Test Summary & Chi-Sq. Statistic & Chi-Sq. d.f. & Prob. \\
\hline Cross-section random & 9.306981 & 5 & 0.0974 \\
\hline
\end{tabular}

Berdasarkan tabel 2, nilai Chi-square statistic adalah 9.306981 yang mana lebih kecil daripada nilai tabel Chi-square dengan a sebesar 0.05 dan degree of freedom $(\mathrm{df})=5$ $(9.306981<11.0705)$ sehingga dapat disimpulkan $\mathrm{H}_{0}$ tidak dapat ditolak. Nilai $p$-value dari cross section random 0.0974 yang mana lebih besar daripada alpha $0.05(0.0974>0.05)$ sehingga dapat disimpulkan $\mathrm{H}_{0}$ tidak dapat ditolak. Hal ini berarti model yang baik digunakan adalah model random effect.

Tabel 3 Hasil Uji t

\begin{tabular}{lrrr}
\hline Model & B & \multicolumn{1}{c}{ T } & Prob \\
\hline SIZE & -4.281290 & -0.755314 & 0.4547 \\
ROE & 85.97366 & 2.268583 & 0.0291 \\
MBV & 6.977662 & 3.875128 & 0.0004 \\
LEV & 2.851066 & 0.204622 & 0.8390 \\
CAPBVA & -0.231162 & 7.194106 & 0.9745 \\
\hline
\end{tabular}

Hasil penelitian menunjukkan bahwa nilai probabilitas market size sebesar 0.4547 yang lebih besar dari 0.05). Hal ini berarti tidak terdapat pengaruh market sizze terhadap stock return. Hasil penelitian ini tidak konsisten dengan Acheampong et al. (2014).

Hasil penelitian menunjukkan bahwa nilai probabilitas kinerja perusahaan sebesar 0.0291 yang lebih kecil dari 0.05). Hal ini berarti terdapat pengaruh kinerja perusahaan terhadap stock return. Hasil penelitian ini konsisten dengan Fidhayatin dan Dewi (2012)

Hasil penelitian menunjukkan bahwa nilai probabilitas nilai perusahaan sebesar 0.0004 yang lebih kecil dari 0.05). Hal ini berarti terdapat pengaruh nilai perusahaan terhadap stock return. Hasil penelitian ini konsisten dengan Fidhayatin dan Dewi (2012).

Hasil penelitian menunjukkan bahwa probabilitas leverage sebesar 0.8390 yang lebih besar dari 0.05). Hal ini berarti tidak terdapat pengaruh leverage terhadap stock return. Hasil penelitian ini tidak konsisten dengan Acheampong, et al. (2014)

Hasil penelitian menunjukkan bahwa nilai probabilitas kesempatan bertumbuh sebesar 0.9745 yang lebih besar dari 0.05 . Hal ini berarti tidak terdapat pengaruh kesempatan bertumbuh terhadap stock return. Hasil penelitian ini konsisten dengan Fidhayatin dan Dewi (2012).

\section{PENUTUP}

Berdasarkan hasil penelitian dan pembahasan yang dipaparkan di atas, dengan menggunakan sampel dari sektor batubara yang terdaftar di Bursa Efek Indonesia periode 20102014, diperoleh kesimpulan bahwa market size, leverage dan kesempatan bertumbuh tidak berpengaruh terhadap stock return. Sedangkan kinerja perusahaan dan nilai perusahaan berpengaruh terhadap stock return. Keterbatasan penelitian adalah penelitian ini hanya menggunakan perusahaan batubara. Untuk penelitian selanjutnya dapat menggunakan sampel yang lebih luas, yaitu perusahaan manufaktur. Penelitian ini hanya menguji lima variabel independen. Penelitian selanjutnya dapat menambahkan variabel independen lain, seperti rasio likuiditas dan operasional perusahaan. 


\section{REFERENSI:}

Acheampong, Prince, Evans Agalega and Albert Kwabena Shibu. 2014. The Effect of Financial Leverage and Market Size on Stock Returns on the Ghana Stock Exchange: Evidence from Selected Stocks in the Manufacturing Sector. International Journal of Financial Research, 5(1).

Anderson, David R., Dennis J. Sweeney, Thomas A. Williams. 2011. Statistic for Business \& Econometrics, Eleventh Edition. Canada: South-western Cengage Learning.

Arthur, J Keown, 2004, Financial Management: Principles and Applications, 1st Ed, USA: Prentice Hall.

Belkaoui, Ahmed Riahi. 2003. Intellectual Capital and Firm Performance of US Multinational Firms: a Study of The Resource-Based and Stakeholder Views. Journal of Intellectual Capital, 4(2):215-226.

Brigham, Eugene F. \& Joel F. Houston. 2009. Fundamentals of Financial Management, Twelfth Edition. United States of America: South Western Cengage Learning.

E. Kieso, Donald, Jerry J, Weygandt \& Teery D. Warfield, 2011. Intermediate Accounting, Edisi 1. Jakarta: Erlangga

Eriemo, Nathanael O. 2014. An Empirical Analysis of the Determinants of Market Capitalization in Nigeria. Developing Country Studies, 4(7).

Fidhayatin, Septy Kurnia dan Nurul Hasanah Uswati Dewi, 2012. Analisis Nilai Perusahaan, Kinerja Perusahaan dan Kesempatan Bertumbuh Perusahaan Terhadap Return Saham Pada Perusahaan Manufaktur yang Listing di BEI.The Indonesian Accounting Review, 2(2), July: 203-2014.

Fuad, M. 2000. PengantarBisnis. Jakarta: Gramedia Pustaka Utama

Gibson, Charles H., 2008. Financial Reporting and Analysis: Using Financial Accounting Information, $11^{\text {th }}$ Edition, South-Western College Publishing, United States of America

Gitman, Lawrence J, Chad J. Zutter. 2012. Principles of Managerial Finance, Thirteenth Edition. United State: Pearson Education.

Gitman, Lawrence J, Chad J. Zutter. 2015. Principles of Managerial Finance, Fourteenth Edition. United State: Pearson Education.

Hayati, Nurul. 2010. Faktor-Faktor Yang Mempengaruhi Price Earnings Ratio (PER) Sebagai Salah Satu Kriteria Keputusan Investasi Saham Perusahaan Real Estate dan Property Di Bursa Efek Jakarta. Jurnal Manajemen dan Akuntansi, 11(1).

John, J.Wild. 2005. Analisis Laporan Keuangan, Buku Satu, Edisi Delapan. Jakarta: Salemba Empat.

Kallapur, Sanjay dan Mark A Trombley. 1999. The Association between Investment Opportunity Set Proxies and Realized Growth. Journal of Bussiness Finance \& Accounting26. April/May: 505-519.

Warsono. 2003. Manajemen Keuangan Perusahaan. Jilid 1. Malang: Bayu Media Publishing.

Widarjono, Agus. 2013. Ekonometrika Pengantar dan Aplikasinya. Yogyakarta: Ekonisia.

White, Gerald I., Ashwinpaul C. Sondhi, \& Dov Fried, 2003.The Analysis and Use of Financial Statements, USA: Wiley \& Sons, Inc. 